\title{
Do Local Firms Benefit from Foreign Direct Investment? An Analysis of Spillover Effects in Developing Countries
}

\author{
Stephan Gerschewski ${ }^{1}$ \\ ${ }^{1}$ College of Business Administration, Hankuk University of Foreign Studies, Seoul, Korea \\ Correspondence: Stephan Gerschewski, College of Business Administration, Hankuk University of Foreign \\ Studies, 107, Imun-ro, Dongdaemun-gu, Seoul, 130-791, Korea. Tel: 82-10-8945-7293. E-mail: \\ stephange@hufs.ac.kr
}

Received: January 30, 2013 Accepted: February 27, 2013 Online Published: March 28, 2013

doi:10.5539/ass.v9n4p67

URL: http://dx.doi.org/10.5539/ass.v9n4p67

This work was supported by Hankuk University of Foreign Studies Research Fund of 2012.

\begin{abstract}
Developing countries are increasingly recipients of foreign direct investment (FDI). In this regard, governments are attempting to attract FDI due to the expected spillover effects, which relate to benefits in terms of increased productivity of local firms and technology diffusion from multinational enterprises (MNEs) to the domestic economy. However, it is generally not clear whether there are positive or negative spillover effects from FDI to local firms in developing economies. The purpose of this paper is to provide a review of the literature on spillover effects and linkages that arise from FDI in developing countries. Our review suggests that there tends to be negative intra-industry productivity spillover effects (i.e., spillovers between MNEs and local firms in the same industry). This may be explained by the fact that MNEs crowd out local competitors that are not able to compete against MNEs, and by the concept of "absorptive capacity" which implies that local firms may not be able to assimilate and absorb knowledge of MNEs. However, we find evidence for positive inter-industry spillovers through linkages between MNE affiliates and suppliers in different industry sectors which may be attributed to the benefits for MNEs in transferring knowledge and technology to their local suppliers. The study offers suggestions for future research.
\end{abstract}

Keywords: foreign direct investment, spillover effect, developing country, linkage, multinational enterprise, productivity

\section{Introduction}

Foreign direct investment (FDI) has become an increasingly important characteristic in the economies of developing countries. The inward stock of FDI in developing countries almost doubled from 1980 to 1990 and increased from $\$ 1735$ billion (23.2\% share of total world inward FDI) in 2000 to $\$ 6625$ billion (32.4\% share) in 2011 (UNCTAD, 2012). This is remarkable in that there has been a change in the attitude of many developing countries towards FDI. While there has been generally a very hostile attitude towards multinational enterprises (MNEs) and FDI up to the 1970s, this has recently changed considerably into a more cooperative policy towards MNEs (Eden \& Lenway, 2001). One of the reasons why governments in developing countries changed their policies may be attributed to the potentially positive impacts of FDI. Governments often attempt to attract FDI as they expect a boost of their economy and increase in the productivity of local firms. According to UNCTAD (1999), the most important contribution of MNEs for developing countries lies in the area of technology. In this respect, one of the main expectations of FDI for host country governments represents the technology diffusion from MNEs to local firms (Meyer, 2004). This implies that intangible assets, such as knowledge and technology that are transferred from MNEs to its foreign affiliates, are "spilled over" to local firms. Spillover effects occur "when local firms benefit from the MNCs affiliate's superior knowledge of product or process technologies or markets, without incurring a cost that exhausts the whole gain from the improvement" (Blomström \& Kokko, 1997: 12). Thus, spillovers arise when MNEs cannot reap all the benefits from internalising their activities. It has been suggested that spillover effects from FDI are the most significant channels for the dissemination of modern, advanced technology (Blomström, 1989). 
In addition, when entering a country through FDI, MNEs often set up direct linkages to suppliers in the host country. Linkages are defined as non-equity relationships with suppliers or customers and are a crucial channel for knowledge diffusion (Giroud, 2003). Thus, it seems that spillovers and linkages are an important means for knowledge transfer to developing countries.

However, it is generally not clear whether spillovers reveal more positive or negative effects on local firms. Despite the policy relevance, the impact of FDI on host countries is not well understood. As Rodrik (1999: 39) puts it, "today's policy literature is filled with extravagant claims about positive spillovers from FDI,... [yet] the hard evidence is sobering".

The purpose of this study is to review and shed light on the phenomenon of spillover effects of FDI in developing countries. We examine the determinants of linkages and look at empirical studies that analyse the emergence and amount of spillovers. In addition, we critically evaluate vertical and horizontal spillovers and examine to which extent spillovers and linkages affect local firms in developing countries. The increasingly important role of FDI in the world economy and the implications for developing countries were motivating factors for conducting this study. Due to the dependence of many developing countries on inward FDI (e.g., UNCTAD, 2012), the study of the impacts of FDI is highly relevant and induced the writing of this paper.

The study is structured as follows. In the next section, we provide some theoretical background to spillovers which is followed by an investigation of intra-industry (=horizontal) and inter-industry (=vertical) spillovers. The paper concludes by stating the limitations of the study and offering potential avenues for future research.

\section{Theoretical Models for the Relationship between FDI and Technology Spillover Effects}

In order to better understand the relationship between FDI and technology spillovers, Findlay (1978) introduced a pioneering model. This model assumes that the rate of technological diffusion from an advanced country to a backward region depends on two factors. First, the greater the distance between two countries in terms of development, the greater is the pressure for change and the more quickly new technology is adopted. Therefore, the larger the technological gap between foreign and domestic firms, the larger are the spillovers. The second assumption of Findlay (1978) is that the speed of technological diffusion depends on the extent to which foreign firms pervade the local market. In this respect, Findlay (1978) compared technological diffusion with a contagious disease. This implies that the more quickly the MNE builds up upstream and downstream networks in the industry, the more rapid are technology transfers to local firms as they gain access to these networks as suppliers.

Findlay (1978) based his model on an earlier work of Gerschenkron (1962). Gerschenkron (1962) introduced the concept of the "technology gap" which indicates that the larger the technological gap between two firms, the bigger the spillover effects. Thus, Gerschenkron (1962) assumes that spillovers are increasing with the difference in technology levels between domestic and foreign firms in an industry. This hypothesis is highly relevant especially for developing countries as there is often a large technology gap between MNE affiliates and local firms. However, as is shown later in this paper, the concept of the technology gap is controversial and there are mixed results from recent, empirical evidence.

\section{Definition of Spillovers and Linkages}

Spillovers are generally measured as the impact of the presence of MNEs on the productivity in local firms. Productivity spillovers take place when the entry or presence of MNE affiliates lead to productivity benefits for local firms and the MNEs are not able to fully internalise the full value of these benefits (Blomström, Kokko, \& Zejan, 2000). It is difficult to measure productivity spillovers because "knowledge flows... leave no paper trail by which they may be measured and tracked" (Krugman, 1991: 53). Spillovers can be distinguished into two types: (1) horizontal spillovers (=intra-industry spillovers) and (2) vertical spillovers (=inter-industry spillovers).

Horizontal spillovers arise within the same industry and consist of knowledge and technology spillovers from MNEs to local competitors. On the other hand, vertical spillovers arise through backward and forward linkages from MNEs to local suppliers and customers. Backward linkages comprise all the relations of MNEs that are established with supplier firms, whereas forward linkages consist of relations established with customers in the host country (UNCTAD, 2001). It is important to differentiate between these two types of spillovers as there are different mechanisms involved for their emergence.

\section{Intra-Industry Spillover Effects}

Intra-industry (or horizontal) spillovers pertain to spillovers that occur between MNE affiliates and local firms in the same industry sector. Most studies recognise four different channels through which productivity spillovers 
can take place. These are (1) demonstration effects, (2) movement of labour (i.e., labour turnover), (3) competition effects, and (4) market access spillovers (export externalities).

As for the demonstration effects, through exposure to the superior technology of MNEs, local firms and entrepreneurs attempt to adapt to this technology by imitating or reverse engineering (Wang \& Blomström, 1991) Imitation is regarded as the classic mechanism for productivity spillovers. Before the MNE enters the host country, local firms do not have the knowledge about technological innovation or it is too costly for them to introduce new technologies (Saggi, 2002). As the MNE introduces new technology, the uncertainty is decreasing, thereby leading to knowledge diffusion to local firms (Meyer, 2004). Saggi (2002) mentioned the geographical proximity as a crucial prerequisite of the demonstration effect, especially for developing countries as they are not as well integrated into the world economy. The main benefit of the demonstration effect can be seen in the expansion of set of technologies that may become available for local firms (Saggi, 2002; Hoekman, Maskus, \& Saggi, 2005).

The second channel for knowledge diffusion refers to the movement of labour. It is shown that MNEs may provide more training for their employees and invest more in staff development than local firms (Gerschenberg, 1987), and, thus, may build local human capital. Spillovers occur when these MNE employees move to other local firms. Thus, the employees transfer their gained knowledge from MNEs to local companies, thereby increasing the productivity of local firms (Meyer, 2004). It is relatively difficult to measure the effects of labour turnover empirically as it would involve interviewing managers who used to work for MNEs and then estimate the knowledge which is transferred to the domestic firms. However, some studies showed that labour turnover plays an important role for productivity spillovers. For example, Katz (1987) argued that managers of locally-owned firms in Latin America often started their career in MNE affiliates before they moved to local companies. Pack (1997) provided another example for technology dissemination by labour turnover. In a study of Taiwanese firms in the 1980s, Pack (1997) found that almost 50\% of all engineers and approximately $63 \%$ of all skilled workers left MNEs to work for Taiwanese local firms, thus increasing the productivity of the domestic companies. It is often argued that labour turnover is the most important channel for spillovers (Görg \& Greenaway, 2004).

Another channel which is commonly regarded in the literature as a spillover channel refers to increased competition (Blomström \& Sjöholm, 1999). This implies that local firms are forced to become more efficient when MNEs enter the local market (Görg \& Strobl, 2001). In order to remain competitive, local firms have to update their technology or use it more efficiently, thus yielding productivity gains. The competition effect can also increase the speed of adoption of new technology or the speed for imitating it (Görg \& Greenaway, 2004). However, increased competition can also lead to productivity losses for local firms. For example, Aitken and Harrison (1999) pointed out in their study of 4000 Venezuelan companies that the productivity of wholly domestically owned firms decreases when FDI increases. They stated that the presence of MNEs leads to a loss of market share for domestic firms and referred to the "market stealing effect" of MNEs (Aitken \& Harrison, 1999: 606). As a result, the presence of MNEs may lead to the crowding out of local firms.

The fourth channel for productivity spillovers refers to export externalities. MNEs that are export-oriented can act as export catalysts to local companies. Thus, local firms can learn how to penetrate export markets (Buckley, Clegg, \& Wang, 2002). Buckley et al. (2002) called these effects "market access spillovers". Aitken, Hanson, and Harrison (1997) examined in a study of 2104 Mexican manufacturing plants the relationship between FDI and the export behaviour of Mexican local firms. The authors reached the conclusion that foreign owned enterprises are a natural conduit for information about foreign markets and technology, thereby enhancing the export prospects for local companies.

\subsection{Empirical Evidence for Intra-Industry Spillover Effects in Developing Countries}

There have been many empirical studies about productivity spillovers in developing countries and the results are mixed. There is generally no consistent evidence about positive externalities from MNEs to local firms in the same sector in developing countries (Alfaro \& Rodriguez-Clare, 2004).

The empirical studies differ in terms of the research methodology and the type of data and can be distinguished into studies that use cross-sectional data and studies which employ panel data. In addition, there is a distinction into firm-level and industry-level data.

As for the earlier research about productivity spillovers, most studies used cross-sectional data. For example, Blomström and Persson (1983) examined whether the technical efficiency of Mexican plants is associated with spillovers of FDI. Using labour productivity to measure the spillover effects, Blomström and Persson (1983) concluded that there is a positive relationship between foreign participation and the efficiency of domestic plants. 
Thus, they found positive spillover effects for domestic plants in Mexico. Consistent with Blomström and Persson (1983), Kokko (1994) also found statistically significant positive effects of the presence on MNEs on the productivity of Mexican domestic firms. In line with Blomström and Persson (1983), Kokko (1994) utilised cross-sectional and industry-level data.

In contrast to research with cross-sectional data, studies that use panel data often come to different results. For instance, Aitken and Harrison (1999) conducted a study about the impact of FDI on Venezuelan plants and found that increased foreign equity participation in Venezuelan plants (with less than 50 employees) is associated with higher performance. However, they found no productivity spillover effects of MNEs to domestic firms. Instead, Aitken and Harrison (1999) revealed negative spillover effects in that the productivity of wholly owned domestic firms decreases as the amount of FDI increases. Kathuria (2000) also reported negative spillover effects in the Indian manufacturing industry. Examining panel data from 1976-1989, Kathuria (2000) found that the presence of MNEs is negatively correlated with the productivity of domestic firms in the same sector. Similarly, Suyanto and Salim (2013) found evidence that FDI decreases the technical efficiency of local Indonesian pharmaceutical firms. In a study of the Indian pharmaceutical industry, Feinberg and Majumdar (2001) examined the extent of technology R\&D spillovers from MNEs to local firms and found spillover effects within the MNEs, but did not find technology spillover effects to local firms. Feinberg and Majumdar (2001) underlined the importance of the Indian government policy toward FDI that influenced the extent of spillover effects. Haddad and Harrison (1993) analysed firm- and industry-level data in Morocco for the period from 1985-1989. In contrast to Feinberg and Majumdar (2001), they did not find evidence for any statistically significant effects for either positive or negative spillover effects. This is consistent with Wooster and Diebel (2010: 641) who concluded in a meta-regression analysis of 32 spillover studies in developing countries that "the evidence of intra-sectoral spillovers from FDI in developing countries is weak, at best". In sum, most of the studies that used cross-sectional data found positive spillover effects for local firms in developing countries, whereas studies with panel data were more likely to show negative or insignificant effects.

One drawback of cross-sectional analysis is that it is not possible to distinguish whether FDI actually increases the productivity of local firms or whether MNEs just invest in inherently more productive sectors (Blalock \& Gertler, 2003). Moreover, cross-sectional data rely on one single data point. Unlike cross-sectional data, panel data enable an analysis over a longer time period. Therefore, Görg and Strobl (2001) argued that panel data studies with firm-level data are the most appropriate framework for measuring spillover effects.

\subsection{Explanations for Negative Intra-Industry Spillover Effects}

Contrary to the theoretical assumptions about positive spillovers through four spillover channels mentioned earlier in this paper, the empirical evidence also reports negative spillover effects.

In explaining this paradox, Aitken and Harrison (1999) referred to the competition effect and stated that the presence of MNEs crowds out local firms that are not able to compete against MNEs. Another main explanation is related to the host country and industry characteristics. Cohen and Levinthal (1989) argued that the extent of spillovers depends on the concept of "absorptive capacity", which is defined as the "firm's ability to identify, assimilate and exploit knowledge from the environment" (Cohen \& Levinthal, 1989: 569). This implies that the technological capabilities of a firm are crucial for absorbing spillovers. Lall (1996) also noted that the impact of FDI depends on the level of development already achieved in the country as well as on the indigenous skills and capabilities. Based on the concept of absorptive capacity, Wang and Blomström (1992) argued that spillovers do not arise automatically from the presence of MNEs. Instead, indigenous firms need to invest in "learning activities" to benefit from spillovers, thus emulating knowledge of MNEs. In addition, Wang and Blomström (1992) stated that the transfer of technology is accelerated by a more competitive business environment. In a similar vein, Crespo and Fontoura (2007) noted that the absorptive capacity of local firms is a precondition for successfully benefiting from FDI spillovers. Concluding from "absorptive capacity", the failure of horizontal spillover effects can be partly explained by the inability of local firms to absorb knowledge.

The concept of "absorptive capacity" contradicts the technology hypothesis of Gerschenkron (1962). Whereas Gerschenkron (1962) argued that the higher the technology gap between two firms the larger the spillover effects, Cohen and Levinthal (1989) found that there is no spillover effect between two firms in an industry, when the technology gap is too high.

Empirical evidence is generally supporting the concept of "absorptive capacity" rather than Gerschenkron's (1962) technology gap hypothesis. Haddad and Harrison (1993) found that there are spillover effects between foreign firms and domestic firms only when the initial technology gap is low and not too large. Kathuria (2000) differentiated between "scientific" subgroups and "non-scientific" subgroups of Indian manufacturing firms and 
found positive spillovers for the "scientific" subgroups. Thus, Kathuria (2000) concluded that the amount of spillovers arises not automatically because of the MNE presence, but "depend to a large extent on the efforts of local firms to invest in learning or R\&D activities so as to decodify the spilled knowledge" (Kathuria, 2000: 364). Similarly, in a study of Chinese high-tech firms, Liu and Buck (2007) found evidence that foreign MNEs' R\&D activities had positive impacts on the innovation performance of local firms only when the precondition of absorptive capacity was met.

\section{Inter-Industry Spillover Effects}

In contrast to horizontal spillovers, inter-industry spillovers from FDI operate via the linkages between the MNE's foreign affiliate and its local suppliers and customers. Backward linkages arise from the relationships between foreign affiliates and suppliers, whereas forward linkages refer to the contacts with customers (UNCTAD, 2001). Linkages can be defined as "the direct relationships established by firms in complementary activities which are external to 'pure' market transactions" (Lall, 1980: 204).

As MNEs enter foreign markets, they have three strategic options with regard to obtaining inputs. First, they can import inputs from other parts of the MNE or from independent suppliers. Second, they can produce them locally in-house ("internalisation"). Third, MNEs can source inputs locally from domestic suppliers (UNCTAD, 2001). When MNEs choose the third option, they build up backward linkages with local suppliers.

\subsection{Backward Linkages}

Giroud (2003) underlined the importance of backward linkages and noted that these linkages are of particular importance for host-developing countries as they provide opportunities for production and employment of domestic suppliers. Moreover, Giroud (2003) argued that backward linkages offer a direct channel for knowledge diffusion. Lall (1996) also mentioned the importance of backward linkages, as they involve greater interaction than normal market relations between anonymous buyers and sellers, e.g., transfer of information. The channels that include direct knowledge transfer from foreign affiliates to local suppliers are various (Javorcik, 2004). For instance, affiliates can transfer knowledge to local firms by offering technical assistance, by providing management training, by improving quality control, by assisting in the purchase of raw materials or by supporting in the organization of production processes. Another channel arises through the higher requirements for product quality and on-time delivery to MNEs which forces domestic suppliers to upgrade management or technological capabilities and become more efficient. In addition, the entry of MNEs increases the demand for intermediate products. As a result, local suppliers can reap economies of scale (Javorcik, 2004).

\subsection{Determinants of Backward Linkages}

It is argued in the literature that the type of entry strategy influences the extent of linkages. Chen, Chen, and $\mathrm{Ku}$ (2004) examined MNEs and local linkages in the Taiwanese manufacturing sector and noted that joint-ventures are more likely to develop local linkages than greenfield projects. Meyer (2004) noted that greenfield investments are regarded as yielding positive spillovers, whereas acquisitions rather do not contribute to spillovers. Scott-Kennel (2007) argued that there are likely to be stronger linkages when MNEs enter a host country through mergers and acquisitions (M\&As) than through greenfield projects, as MNEs usually take over the already existing supplier relationships.

As far as the ownership structure of MNEs is concerned, there are divergent opinions as to whether the ownership structure affects the extent of spillovers and linkages. Javorcik (2004) found that firms with partial foreign ownership are more likely to source locally than companies with full foreign ownership. The author argued that spillovers from vertical (=backward) linkages are more likely to come from firms with partial foreign ownership, as these firms are more likely to source locally. Similarly, in a study of Romanian firms, Javorcik and Spatareanu (2008) found evidence of vertical spillovers in projects with shared domestic and foreign ownership, but not with wholly-owned foreign subsidiaries. However, Blomström and Sjöholm (1999) contradicted the findings of Javorcik (2004). They oppose the assumption that local participation with MNEs leads to higher spillovers. Often governments impose certain restrictions on foreign ownership, e.g., by allowing only joint-ventures for the market entry of MNEs. In their study of Indonesian firms, Blomström and Sjöholm (1999) found that spillovers to local firms are not affected by the degree of foreign ownership. Their results showed that there is no significant difference in spillovers of minority and majority-owned foreign establishments. As a result, local participation with MNEs did not facilitate technology diffusion. Blomström and Sjöholm (1999) concluded that technology spillovers are rather the result of increased competition that follows FDI than the ownership sharing of MNEs. 
There seems to be a consensus that the market orientation of MNE affiliates in the host country plays an important role for spillovers. Reuber, Crookell, Emerson, and Gallais-Hamonno (1973) found in their study of 64 projects in developing countries that domestic oriented affiliates source more locally from local suppliers than export-oriented foreign affiliates. Thus, they argued that projects which are oriented towards local markets are more fully integrated into the local economy than export-oriented projects. Javorcik (2004) reached the same conclusion in a study of Lithuanian firms which revealed that domestic-market oriented affiliates generate more productivity spillovers to local suppliers than export-oriented affiliates.

Another determinant which influences the extent of linkages is concerned with the internal operations of MNEs. This includes, for example, the organisational culture or human resource management practises (Meyer, 2004). In this respect, a crucial point for MNE spillovers is the knowledge transfer between the MNE and the foreign subsidiary. A prerequisite for spillovers is the sharing of knowledge between MNE and the affiliate in the host country (Meyer, 2004). Nonaka and Takeuchi (1995) provided a comprehensive framework for knowledge management and intra-firm knowledge creation which involves several factors, such as environmental scanning or creative chaos that lead to efficient knowledge creation in an organisation.

\subsection{Forward Linkages}

Forward linkages consist of linkages between MNE affiliates and customers in the host country. Meyer (2004) noted that downstream businesses can benefit through similar complementary channels as suppliers through backward linkages. For example, local firms can act as marketing outlets for foreign investors and may receive training in sales techniques or supply of sales equipment. Aitken and Harrison (1999) argued that spillovers from forward linkages are very important in many industries and noted that the downstream effects of FDI are in general more beneficial than upstream effects.

However, there is generally much less evidence on forward linkages than on backward linkages. In sum, forward linkages have not received much attention in the literature and there tends to be a lack of empirical evidence in comparison to backward linkages (Blomström \& Kokko, 1997).

\subsection{Empirical Evidence for Linkages in Developing Countries}

Generally, most studies of productivity spillover effects examined spillovers that take place within the same industry (=horizontal spillovers). As a consequence, there is a lack of empirical studies for examining the vertical spillover effects which arise through backward or forward linkages. Some of the empirical studies for vertical spillovers in developing countries are outlined in the following.

Javorcik (2004) argued that spillovers are more likely to arise through backward linkages and noted that MNEs attempt to prevent technology from leaking to local competitors. To this end, MNEs undertake certain efforts, such as paying high wages to prevent labour turnover to local firms and locating their affiliates in places where local firms have less imitative capacity. Another method to prevent leakage of technology is by protection of intellectual property (Javorcik, 2004). Therefore, Javorcik (2004) concluded that there are often no or negative horizontal spillovers and argued that backward linkages are the most likely channels for spillovers. Utilising firm-level panel data for Lithuanian firms in the period of 1996-2000, Javorcik (2004) revealed three main results. First, the presence of MNEs was associated with an increase in productivity of supplying firms. Second, productivity benefits for local firms were associated with partially-owned foreign projects rather than fully-owned foreign projects. Third, Javorcik (2004) did not find any evidence of intra-industry spillovers which is consistent with earlier firm-level studies of developing countries (e.g., Feinberg \& Majumdar, 2001).

Blalock and Gertler (2003) also found strong backward linkage effects in a panel data set of Indonesian manufacturing firms from 1988 to 1996. They explained their findings by the deliberate technology transfer of MNEs to local suppliers in order to lower prices and increase competition in upstream markets.

Another empirical study was carried out by Kugler (2006). By examining intra- and inter-industry spillovers for ten manufacturing sectors in Colombia for the period of 1974 to 1998, Kugler (2006) found evidence for positive inter-industry spillovers, whereas horizontal spillovers were only statistically important in one sector. Similarly, Iyer (2009) found positive vertical spillovers and linkages in a study of the Indian manufacturing industry from 1989-2004. To recapitulate, empirical evidence for developing countries often shows significant vertical spillover effects through backward linkages. This contrasts with the rather mixed results of horizontal spillovers.

\section{Limitations of the Study}

It should be noted that this study has some limitations. In order to keep the scope of the paper manageable, the study does not review the role of the host country policy. The policy environment may play an important role for 
linkages, especially in developing countries. For example, Feinberg and Majumdar (2001) noted in their paper the importance of the Indian government policy toward FDI.

Another limitation is that collaborative linkages and network linkages, such as strategic alliances, are not considered in this study. The literature strand for these kinds of linkages is based on the network approach and strategic linkage theory (e.g., Nohria \& Garcia-Pont, 1991; Johanson \& Mattsson, 1988). Strategic linkage theory contends that firms can gain access to capabilities by linking with local firms (e.g., Chen \& Chen, 1998). This paper is based on conventional FDI theory which states that MNEs internalise their activities in order to exploit their existing firm-specific advantages (e.g., Hymer, 1976; Rugman, 1980).

\section{Conclusion}

Spillover effects from MNEs to local firms and linkages are often essential for developing countries as they can serve as key channels for knowledge diffusion. In evaluating the spillover effects, a differentiation between horizontal spillovers and vertical spillovers should be made, and there are different empirical results for both types.

As for horizontal spillovers, the empirical evidence reveals mixed results (Wooster \& Diebel, 2010). Whereas earlier studies that use cross-sectional data and industry level data, find positive spillovers, more recent studies with panel data and firm level data reveal negative horizontal spillovers. According to Görg and Strobl (2001), the studies with panel data suggest a better framework for measuring spillover effects, as panel data are longitudinal and allow a better association between FDI and spillovers. Thus, it seems that there is more evidence for negative horizontal spillovers to domestic firms in developing countries. In other words, the presence of MNEs is likely to lead to productivity losses for local competitors of MNEs in developing countries. This implies that MNEs are successful in preventing leakage of their technology to local competitors, especially by protection of intellectual property (Javorcik, 2004).

Another important factor that may explain negative spillovers is absorptive capacity. This means that the extent of spillovers depends largely on the ability of local firms to emulate and integrate the knowledge of MNEs. Thus, it should be mentioned that spillovers are not necessarily automatic and guaranteed (Wang \& Blomström, 1992; Crespo \& Fontoura, 2007).

On the other hand, our review suggests that there is more evidence for positive vertical spillovers in developing countries. In contrast to horizontal spillovers, vertical spillovers through backward linkages seem to be more likely channels for knowledge transfer. This can be largely attributed to the benefits for MNEs in transferring knowledge and technology to their local suppliers. MNEs often deliberately transfer knowledge to local suppliers or customers, whereas they are not interested in the leakage of technology to local rivals (Javorcik, 2004).

In sum, spillovers are a complex phenomenon and depend on several factors and characteristics, such as host country and industry characteristics. It has been shown that productivity spillovers of MNEs to local firms can represent a crucial factor for developing countries in advancing their economy. Thus, it becomes increasingly important for local firms to invest in learning activities in order to reduce the technology gap between MNEs and local firms, thereby absorbing the spillover effects. However, the negative effects of the presence of MNEs, such as the crowding out of local firms, should not be neglected and be borne in mind.

\section{Suggestions for Future Research}

Most of the research on spillovers and linkages is focused on horizontal spillovers (i.e., intra-industry spillovers) (e.g., Wooster \& Diebel, 2010; Görg \& Greenaway, 2004; Iyer, 2009). However, there is generally a lack of research on vertical spillovers. Therefore, we suggest that future research focuses on examining vertical spillovers and linkages and how they arise. In particular, the firm-level as the unit of analysis may offer a fruitful area for future research. For example, the relationship between affiliates and local firms could be examined in more detail, including the determinants and factors which lead to linkages between affiliates and local firms. In addition, many studies take a macro-perspective when examining spillover effects (e.g., Görg \& Greenaway, 2004). Future research may focus more on the micro-level perspective and explore the interactions between MNE affiliates and local firms. A potential research design might involve a quantitative survey approach or qualitative interviews with foreign affiliates and local companies in order to examine the motives and factors of linkages. In particular, a qualitative research approach may lead to "rich" results.

In addition, the main focus of the extant literature has been on measuring the impact of FDI on domestic firms in the manufacturing sector (e.g., Iyer, 2009). Yet, there is a lack of research investigating the spillover effects for companies in the service industry. It might be interesting to examine the implications of FDI spillover effects for service companies and evaluate whether there are differences between manufacturing and service firms. 
In conclusion, spillover effects are a broad and extremely complex phenomenon, and there are some areas that are not yet fully understood. Given the increasing importance of FDI in the world economy, studying the impacts of FDI on developing countries is becoming critical for the future. As important consequences of FDI, spillover effects and linkages in local economies are and remain relevant issues for further research.

\section{References}

Aitken, B., \& Harrison, A. E. (1999). Do domestic firms benefit from direct foreign investment? Evidence from Venezuela. The American Economic Review, 89(3), 605-618. http://dx.doi.org/10.1257/aer.89.3.605

Aitken, B., Hanson, G. H., \& Harrison, A. E. (1997). Spillovers, foreign investment, and export behavior. Journal of International Economics, 43(1-2), 103-132. http://dx.doi.org/10.1016/S0022-1996(96)01464-X

Alfaro, L., \& Rodriguez-Clare, A. (2004). Multinationals and linkages: An empirical investigation. Economia, 4(2), 113-169. http://10.1353/eco.2004.0012

Blalock, G., \& Gertler, P. (2003). Technology from foreign direct investment: Welfare gains through the supply chain. Cornell University and University of California at Berkeley, mimeo.

Blomström, M. (1989). Foreign investment and spillovers: A study of technology transfer to Mexico. London: Routledge.

Blomström, M., \& Kokko, A. (1997). How foreign investment affects host countries. Policy research working paper no. 1745.Washington, D.C.: International Trade Department, World Bank.

Blomström, M., \& Persson, H. (1983). Foreign investment and spillover efficiency in an underdeveloped economy: Evidence from the Mexican manufacturing industry. World Development, 11, 493-501. http://dx.doi.org/10.1016/0305-750X(83)90016-5

Blomström, M., \& Sjöholm, F. (1999). Technology transfer and spillovers: Does local participation with multinationals matter? European Economic Review, 43(4-6), 915-923. http://dx.doi.org/10.1016/S0014-2921(98)00104-4

Blomström, M., Kokko, A., \& Zejan, M. (2000). Foreign direct investment: Firm and host country strategies. London: Macmillan.

Buckley, P. J., Clegg, J. \& Wang, C. (2002). The impact of inward FDI on the performance of Chinese manufacturing firms. Journal of International Business Studies, 33(4), 637-655. http://dx.doi.org/10.1057/palgrave.jibs.8491037

Chen, H., \& Chen, T. J. (1998). Network linkages and location choice in foreign direct investment. Journal of International Business Studies, 29(3), 445-467. http://dx.doi.org/10.1057/palgrave.jibs.8490002

Chen, T. J., Chen, H., \& Ku, Y. H. (2004). Foreign direct investment and local linkages. Journal of International Business Studies, 35(4), 320-333. http://dx.doi.org/10.1057/palgrave.jibs.8400085

Cohen, W. M., \& Levinthal, D. A. (1989). Innovation and learning: The two faces of R\&D. The Economic Journal, 99(397), 569-596. http://dx.doi.org/10.2307/2233763

Crespo, N., \& Fontoura, M. P. (2007). Determinant factors of FDI spillovers - What do we really know? World Development, 35(3), 410-425. http://dx.doi.org/10.1016/j.worlddev.2006.04.001

Eden, L., \& Lenway, S. (2001). Introduction to the symposium multinationals: The Janus face of globalization. Journal of International Business Studies, 32(3), 383-400. http://dx.doi.org/10.1057/palgrave.jibs.8490973

Feinberg, S. E., \& Majumdar, S. K. (2001). Technology spillovers from foreign direct investment in the Indian pharmaceutical industry. Journal of International Business Studies, 32(3), 421-437. http://dx.doi.org/10.1057/palgrave.jibs. 8490975

Findlay, R. (1978). Relative backwardness, direct foreign investment, and the transfer of technology: A simple dynamic model. Quarterly Journal of Economics, 92, 1-16. http://dx.doi.org/10.2307/1885996

Gerschenberg, I. (1987). The training and spread of managerial know-how. A comparative analysis of multinationals and other firms in Kenya. World Development, 15, 931-939. http://dx.doi.org/10.1016/0305-750X(87)90043-X

Gerschenkron, A. (1962). Economic backwardness in historical perspective: A book of essays. Cambridge, MA: Belknap Press of Harvard University Press.

Giroud, A. (2003). Transnational corporations, technology, and economic development: Backward linkages and 
knowledge transfer in South East Asia. Cheltenham: Edward Elgar.

Görg, H., \& Greenaway, D. (2004). Much ado about nothing? Do domestic firms really benefit from foreign direct investment? World Bank Research Observer, 19(2), 171-197. http://dx.doi.org/10.1093/wbro/lkh019

Görg, H., \& Strobl, E. (2001). Multinational companies and productivity spillovers: A meta-analysis. The Economic Journal, 111(475), 723-739. http://dx.doi.org/10.1111/1468-0297.00669

Haddad, M., \& Harrison, A. (1993). Are there positive spillovers from direct foreign investment? Evidence from panel data for Morocco. Journal of Development Economics, 42(1), 51-74. http://dx.doi.org/10.1016/0304-3878(93)90072-U

Hoekman, B. M., Maskus, K. E., \& Saggi, K. (2005). Transfer of technology to developing countries: Unilateral and multilateral policy options. World Development, 33(10), 1587-1602. http://dx.doi.org/10.1016/j.worlddev.2005.05.005

Hymer, S. (1976). The international operations of national firms: A study of direct foreign investment. Cambridge, Mass.: M.I.T. Monographs in Economics.

Iyer, G. C. (2009). Foreign firms and inter-industry spillovers in Indian manufacturing: Evidence from 1989 to 2004. Margin: The Journal of Applied Economic Research, 3(3), 297-317. http://dx.doi.org/10.1177/097380100900300305

Javorcik, B. S. (2004). Does foreign direct investment increase the productivity of domestic firms? In search of spillovers through backward linkages. The American Economic Review, 94(3), 605-627. http://dx.doi.org/10.1257/0002828041464605

Javorcik, B. S., \& Spatareanu, M. (2008). To share or not to share: Does local participation matter for spillovers from foreign direct investment? Journal of Development Economics, 85(1-2), 194-217. http://dx.doi.org/10.1016/j.jdeveco.2006.08.005

Johanson, J., \& Mattsson, L. G. (1988). Internationalization in industrial systems - A network approach. In N. Hood, \& J. E. Vahlne (Eds.), Strategies in global competition (pp. 287-314). London: Routledge.

Kathuria, V. (2000). Productivity spillovers from technology transfer to Indian manufacturing firms. Journal of International Development, $12(3)$, http://dx.doi.org/10.1002/(SICI)1099-1328(200004)12:3<343::AID-JID639>3.0.CO;2-R

Katz, J. M. (1987). Technology creation in Latin American manufacturing industries. New York: St. Martin's Press.

Kokko, A. (1994). Technology, market characteristics, and spillovers. Journal of Development Economics, 43(2), 279-293. http://dx.doi.org/10.1016/0304-3878(94)90008-6

Krugman, P. (1991). Geography and trade. Cambridge, MA: MIT Press.

Kugler, M. (2006). Spillovers from foreign direct investment: Within or between industries? Journal of Development Economics, 80(2), 444-477. http://dx.doi.org/10.1016/j.jdeveco.2005.03.002

Lall, S. (1980). Vertical interfirm linkages in LDCs: An empirical study. Oxford Bulletin of Economics and Statistics, 40, 203-226. http://10.1111/j.1468-0084.1980.mp42003002.x

Lall, S. (1996). Transnational corporations and economic development. In Transnational corporations and world development (pp. 44-72). Geneva: UNCTAD.

Liu, X., \& Buck, T. (2007). Innovation performance and channels for international technology spillovers: Evidence from Chinese high-tech industries. Research Policy, 36(3), 355-366. http://dx.doi.org/10.1016/j.respol.2006.12.003

Meyer, K. E. (2004). Perspectives on multinational enterprises in emerging economies. Journal of International Business Studies, 35(4), 259-276. http://dx.doi.org/10.1057/palgrave.jibs.8400084

Nohria, N., \& Garcia-Pont, C. (1991). Global strategic linkages and industry structure. Strategic Management Journal, 12, 105-124. http://dx.doi.org/10.1002/smj.4250120909

Nonaka, I., \& Takeuchi, H. (1995). The knowledge-creating company: How Japanese companies create the dynamics of innovation. New York: Oxford University Press.

Pack, H. (1997). The role of exports in Asian development. In N. J. Birdsall, \& F. Jaspersen (Eds.), Pathways to growth: Comparing East Asia and Latin America. Washington D.C.: Inter- American Development Bank. 
Reuber, G. L., Crookell, H., Emerson, M., \& Gallais-Hamonno, G. (1973). Private foreign investment in development. Oxford: Clarendon Press.

Rodrik, D. (1999). The new global economy and developing countries: Making openness work. Washington, DC, Overseas Development Council, Policy essay 24: John Hopkins University Press.

Rugman, A. M. (1980). Internalization as a general theory of foreign direct investment: A re-appraisal of the literature. Review of World Economics, 116(2), 365-379. http://10.1007/BF02696864

Saggi, K. (2002). Trade, foreign direct investment, and international technology transfer: A survey. World Bank Research Observer, 17(2), 191-235. http://dx.doi.org/10.1093/wbro/17.2.191

Scott-Kennel, J. (2007). Foreign direct investment and local linkages: An empirical investigation. Management International Review, 47(1), 51-77. http://dx.doi.org/10.1007/s11575-007-0004-6

Suyanto, S., \& Salim, R. (2013). Foreign direct investment spillovers and technical efficiency in the Indonesian pharmaceutical sector: firm level evidence. Applied Economics, 45(3), 383-395. http://dx.doi.org/10.1080/00036846.2011.605554

UNCTAD. (1999). Foreign direct investment and development. UNCTAD series on issues in international investment agreements. New York and Geneva: United Nations.

UNCTAD. (2001). World investment report 2001: Promoting linkages. New York and Geneva: United Nations.

UNCTAD. (2012). World investment report 2012: Towards a new generation of investment policies. New York and Geneva: United Nations.

Wang, J. Y., \& Blomström, M. (1992). Foreign investment and technology transfer: A simple model. European Economic Review, 36(1), 137-155. http://dx.doi.org/10.1016/0014-2921(92)90021-N

Wooster, R. B., \& Diebel, D. S. (2010). Productivity spillovers from foreign direct investment in developing countries: A meta-regression analysis. Review of Development Economics, 14, 640-655. http://dx.doi.org/10.1111/j.1467-9361.2010.00579.x 